\title{
IDADES DO MAGMATISMO GRANíTICO DA REGIÃO DE CARACULO-BIBALA (SW DE ANGOLA) E SUAS IMPLICAÇÕES NA CORRELAÇÃO GEOLÓGICA COM O CINTURÃO RIBEIRA NO SUDESTE DO BRASIL
}

\author{
HEITOR DE CARVALHO* \& COLOMBO C.G. TASSINARI**
}

\begin{abstract}
GEOCHRONOLOGYOFGRANITICMAGMATISMFROMCARACULO-BIBALAREGION (SW ANGOLA) AND ITS CORRELATION WITH RIBEIRA FOLD BELT (SE BRAZIL). Rb-Sr whole-rock analyses of representativegranitic rocks from the Bibala-Caraculo region, southwestern Angola, are used to determine the age and evolution of the acid plutonic events in this segment ofthe Angolan continental crust. The granitoids present a wide range of 1 ithological types and compositions. Three time-intervals have been defined for the magmatism: 1,950 - 1,900 Ma; 1,750 -1,700 Ma; 1,550 -1,500 Ma. The oldest, though not very well defined, was obtained for the Chicalengue granitoid, the second one represents the Serra dos Gandarengos and Chonga granitoids and Luchipa Pungue Granitic Complex and the youngest one comprises the Chicate and Caraculo granitic bodies and Munhino GraniticComplex. The initial "'"Sr/ $/ \mathrm{Sr}$ ratios show characteristic values foreach time-interval, as follows: 1,950-1,900 $\mathrm{Ma}=0,7015 ; 1,750-1,700 \mathrm{Ma}=0,7060$ to 0,$7075 ; 1,550-1,500 \mathrm{Ma}=0,7048-0,7057$, suggesting different sources for the granitoids within each geological period. The ages obtained for the southweastern Angolagranitic rocks are not directly related to the granitogenesis ages ofCosteiro Complex in Brazil, but most of them are chrono-correlated with the prothol it (Sm-Nd model ages) of the Late-Proterozoic metamorphic events of this complex. In addition are presented two K-Ar ages for the basic rocks in S W Angola, with values of 700 and $600 \mathrm{Ma}$, which represent a minumum ages for these rocks and are probably related to the Damara Orogeny.
\end{abstract}

Keywords: Geochronology, Angola, geological correlation, Ribeira Belt, Brazil granitoids.

\begin{abstract}
RESUMO Foram realizadas análises $\mathrm{Rb}-\mathrm{Sr}$, em rochatotal, de rochas granfticas que ocorrem no sudoeste de Angola, visando caracterizar a idade e a evolução deste magmatismo plutônico. Os granitóides apresentam grande variação litológicae composicional, abrangendo desde termos graníticos até granodioríticos. Três intervalos de idades foram defmidos para as manifestacões magmáticas: 1.950 -1.900 Ma, 1. 750 -1.700 Ma e 1. 550 -1.500 Ma. O intervalo mais antigo obtido para o granitóide Chicalengue não foi muito bem definido, mas o segundo inclui os granitóides da Serra dos Gandarengos e da Chonga e o Complexo Granftico Luchipa-Luso. O intervalo mais jovem compreende os corpos graníticos de Chicate e Caraculo e o Complexo Granítico do Munhino. As razões iniciais "Sr/^ $\mathrm{Srmostraram}$ valores característicos para cada intervalo nomeadamente: $1.950-1.900 \mathrm{Ma}=0,7015 ; 1.750-1.700 \mathrm{Ma}=0,7060 \mathrm{a}$ 0,$7075 ; 1.550-1.500 \mathrm{Ma}=0,7048-0,7057$, o que sugere diferentes fontes magmáticas para cada período de magmatismo granítico. As idades obtidas no sudoeste de Angola não são diretamente correlacionáveis com aquelas obtidas para o Complexo Costeiro na área contígua no Brasil, mas muitas delas correlacionam-se com as idades dos protólitos metamórficos que, no Brasil, foram retrabalhados no Proterozóico Superior. Em adição, são apresentadas duas idades K-Ar, obtidas em rochas básicas da área, sendo obtidos os valores de 700 e 600 Ma, interpretadas como idades mínimas e relacionadas ao aquecimento provocado pelaorogenia Damara.
\end{abstract}

Palavras-chaves: Geocronologia, Angola, correlação geológica, FaixaRibeira, granitóides.

INTRODUÇÃO Este trabalho é produto da primeira fase de desenvolvimento do Projeto de Cooperação Científica Internacional Brasil - Portugal $(\mathrm{CNPq}$ - IICT), intitulado "Correlação Geológica Brasil - Angola", em que participam o Instituto Nacional de Geologia de Angola, o Instituto de Geociências da Universidade de São Paulo e o Instituto de Investivação Científica Tropical de Portugal.

A área estudada abrange a região de Caraculo e Bibala no sudoeste de Angola e ocupa cerca de $6.000 \mathrm{~km}^{2}$, correspondendo às folhas $n^{\circ} 334$ (Munhino) e 335 ((Bibala) da carta de Angola na escala 1: 100.000 . Os trabalhos de campo foram efetuados pelo ex-Instituto de Investigação Científica de Angola (Folha $\mathrm{n}^{\circ}$ 334) e ex-Serviço de Geologia e Minas de Angola (Folha $\mathrm{n}^{\mathrm{o}} 335$ ). As análises radiométricas pelos métodos $\mathrm{Rb}-\mathrm{Sr}$ (em rocha total) e K-Ar (em concentrados de minerais) foram realizadas pelo Centro de Pesquisas Geocronológicas do Instituto de Geociências da Universidade de São Paulo, em amostras que se encontravam arquivadas na Htoteca do Instituto de Investigação Científica Tropical, em Lisboa.

Por causa das diferentes denominações dos ciclos orogênicos no Brasil e na África, serão utilizados neste trabalho os termos brasileiros, considerando-se as seguintes correspondências: Brasiliano: Pan-Africano

Transamazônico: Eburneano

Jequié: Limpopo-Liberiano

CONTEXTO GEOLÓGICp A região de CaraculoBibala situa-se na faixa costeira de Angola, numa superfície de erosão cuja altitude oscila entre 500 e $600 \mathrm{~m}$, onde se destacam inselbergs que atingem cotas de até $2.500 \mathrm{~m}$. Esta zona constitui a borda do Cráton Angola-Kasai (SW do Cráton do Congo), que é limitado a sudoeste por uma faixa de rochas brasilianas associadas ao Cinturão Damara-Katanga. Esta área cratôniea sofreu, em Angola, ações tectonomagmáticas relativas ao Ciclo Jequié. As rochas com idades maiores que 2.600 Ma ocorrem desde o Kasai (Zaire) até a região centro-oeste de Angola. Constituem os complexos gabronoríticos e charnockíticos, cuja charnockitização se processou há $2.800 \mathrm{Ma}$ (Cahen et al. 1984), e o complexo granito-migmatítico, cuja idade situa-se entre $2.700 \mathrm{Ma}$

\footnotetext{
* Centro de Geologia, Instituto de Investigação Científica Tropical (IICT), Av. D. Afonso Henriques, 41 /4D, P. 1000, Lisboa, Portugal

** CPGeo, Instituto de Geociências, Universidade de São Paulo, Caixa Posta! 20899, CEP 01498-970, São Paulo, SP, Brasil
} 
(migmatitos) e $2.600 \mathrm{Ma}$ (granitos) (Delhal et al. 1975). Além desses complexos, existem várias seqüências metavulcanossedimentares do tipo greenstone belt com itabiritos, similares às seqüências do Supergrupo Rio das Velhas, no sul do Cráton São Francisco, e grande quantidade de rochas básicas que constituem o Complexo Gabro-Anortosítico do SW de Angola e NW da Namíbia, de idade maior ou igual a $2.160 \mathrm{Ma}$ (Carvalho \& Alves 1990).

O Ciclo Transamazônico encontra-se representado no Cráton Angola-Kasai por rochas granitóides e migmatíticas que ocorrem em volta dos terrenos mais antigos descritos anteriormente.

Entre as atividades relativas ao Proterozóico Médio, merecem destaque as granitizações e intrusões básicas noríticas e doleríticas que se observam no sudoeste de Angola, que serão discutidas com maior detalhe no próximo item.

O Ciclo Brasiliano se encontra bem representado no sudoeste de Angola, onde ocorrem seqüências metassedimentares, granitóides e rochas básicas incluídas no Cinturão Damara-Katanga. Na borda do Cráton de Angola-Kasai, ocorrem somente aquecimentos locais durante este ciclo, provocados pelo desenvolvimento dos cinturões orogênicos que o limitam.

DESCRIÇÃO DOS GRANITÓIDES DA ÁREA A geologia da região do Caraculo-Bibala encontra-se descrita em maior detalhe em Carvalho (1970). Nesta zona, de acordo com os trabalhos de campo realizados e com os dados geocronológicos obtidos, as rochas granitóides foram subdivididas em sete suítes graníticas, que são: Complexo Granítico Luchipa-Pungue $(\mathrm{H})$; Complexo Granítico do Munhino (F); Granitóides da Serra dos Gandarengos (I), da Serra da Chonga (G), do Caraculo (D), do Chicalengue (J) e do Chicate (E) (Fig. 1). Os complexos graníticos incluem também rochas gnáissico-migmatíticas, possivelmente mais antigas, as quais não foram objeto de estudo neste trabalho.

Complexo Granítico Luchipa-Pungue O Complexo Luchipa-Pungue é composto por granitóides não claramente separáveis de rochas gnáissico-migmatíticas, que exibem coloração esverdeada devido a presença de epídoto, clorita e sericita, granulação variável de fina a média; geralmente, os seus minerais ferro-magnesianos encontramse alinhados na mesma direção das seqüências metassedimentares vizinhas.

Pela petrografia (Alves \& Macedo 1965), os granitóides deste Complexo possuem tendências alcalinas e cálcioalcalinas, sendo esta última mais freqüente. Os termos alcalinos são compostos principalmente por granitóides ricos em albita e microclínio, tendo os plagioclásios (albitaoligoclásio) revelado forte microclinização. O mineral máfico mais comum é a biotita. Os granitóides cálcio-alcalinos possuem quantidades equivalentes de microclínio e de andesina e, também, de biotita e muscovita.

Complexo Granítico do Munhino O Complexo Granítico do Munhino ocorre no sudeste da região em estudo (Fig. 1), sendo constituído por granitóides associados a gnaisses e migmatitos. Essas rochas estão em contato com granitóides e com rochas do Complexo Xisto-QuartzíticoAnfibolítico (Carvalho 1970 e Carvalho \& Alves 1990), nas quais associam-se mármores e rochas básicas e ultrabásicas (piroxenitos e hornblenditos).

Fora das zonas de contato, o Complexo Granítico do Munhino é composto por granitos cálcio-alcalinos ricos em hornblenda. A medida que se aproximam das zonas de contatos, estes granitóides vão tornando-se mais empobrecidos em microclínio e enriquecidos em andesina, hornblenda verde (muitas vezes derivadas de piroxênios) e biotita, passando para composição granodiorítica a diorítica. Portanto, os granitóides do Complexo Munhino, aqui estudados, podem corresponder a rochas provenientes de processos endometamórficos que ocorreram no granito do Caraculo durante posicionamento crustal.

Granítóide do Chicate O Granitóide do Chicate ocorre a nordeste da área em estudo, sendo geralmente porfiróide, de granulação grossa e com duas micas.

Junto às zonas de contato a leste e oeste, Carvalho (1970) observou que o Granitóide do Chicate apresenta granulação fina e textura eqüigranular e, localmente, encraves das rochas encaixantes.

Barros et al (1964) descreveram o Granitóide de Chicate como cálcio-alcalino, rico em quartzo, microclínio e oligoclásio-andesina (freqüentemente microclinizados e zonados).

Granitóide do Chicalengue O Granitóide do Chicalengue ocorre na região centro-oeste da área, preservado em meio às rochas do Complexo Luchipa-Pungue (Fig. 1). Esse granito é geralmente porfiróide, de granulação média; na borda leste do maciço, possui granulação fina e textura eqüigranular (Carvalho 1970).

Geoquimicamente, o Granito de Chicalengue possui tendência alcalina e composição monzonítica (Barros et al. 1964). Essas rochas apresentam megacristais de microclínio e de oligoclásio que se destacam em meio a matriz quartzofeldspática eqüigranular.

Granitóide da Serra dos Gandarengos A Serrados Gandarengos forma um importante relevo na zona lestenordeste da região em estudo, cuja altitude máxima é de 2.087 $\mathrm{m}$, ocupando uma superficie com $2.000 \mathrm{~km}^{2}$ aproximadamente (Fig. 1). Esta serra é constituída essencialmente por granitóides, com textura porfiróide e granulação média a fina.

A leste da área, o Granitóide da Serra dos Gandarengos está em contato com o denominado "Granito Regional", datado por Torquato et al (1979), a cerca de $90 \mathrm{~km}$ a leste, em 2.160 $\pm 42 \mathrm{Ma}(\mathrm{ri}=0,702 \pm 0,001)$ por meio de diagrama isocrônico $\mathrm{Rb}-\mathrm{Sr}$ em rocha total. Em meio a este granitóide ocorrem intrusões de outros corpos graníticos menores com cerca de $1.557 \pm 35 \mathrm{MA}$. e razão ${ }^{87} \mathrm{Sr}{ }^{86} \mathrm{Sr}$ inicial de $0,7132 \pm 0,0007$.

Conforme Alves \& Macedo (1965), o Granitóide da Serra dos Gandarengos possui natureza cálcio-alcalina, por vezes alcalina. Contém essencialmente quartzo, oligoclásio e/ou andesina e microclínio pertítico. Os minerais acessórios mais importantes são biotita, muscovita e clorita.

Granitóide da Serra da Chonga A Serra da Chonga constitui maciço granítico, com altitude de $1.500 \mathrm{~m}$, que sobressai de zona aplainada na qual cotas oscilam entre 500 e $600 \mathrm{~m}$, aproximadamente.

Os granitóides dessa serra geralmente são leucocráticos, possuindo muscovita, microclínio, plagioclásio e pouca hornblenda. A textura varia de eqüigranular média a porfiróide grossa; apresentam tendências alcalinas (Barros et al 1964), marcadas em alguns locais pela ocorrênciade quartzo-sienitos.

Granitóide do Caraculo O Maciço Granitóide do Caraculo ocorre junto ao limite sudoeste da área (Fig. 1). E formado por duas ocorrências separadas pelos Complexos Gnáissico-Migmatítico e Xisto-Quartzítico-Anfíbolítico, com mármores associados que, por vezes, aparecem como tetos pendentes dentro do granitóide.

O Granitóide do Caraculo exibe granulação desde fina a média até grossa, quando possui textura porfiróide. Mineralogicamente, é composto por quartzo, plagioclásio, microclínio e biotita; os plagioclásios, por vezes, apresentamse microclinizados.

Próximos da zona de contato com o Complexo XistoQuartzítico-Anfibolítico, o granitóide apresenta enriquecimento em minerais ferro-magnesianos, notadamente em hornblenda verde, tendo em vista que, a exemplo do Complexo Munhino, este granitóide se endometamorfisa junto ao 


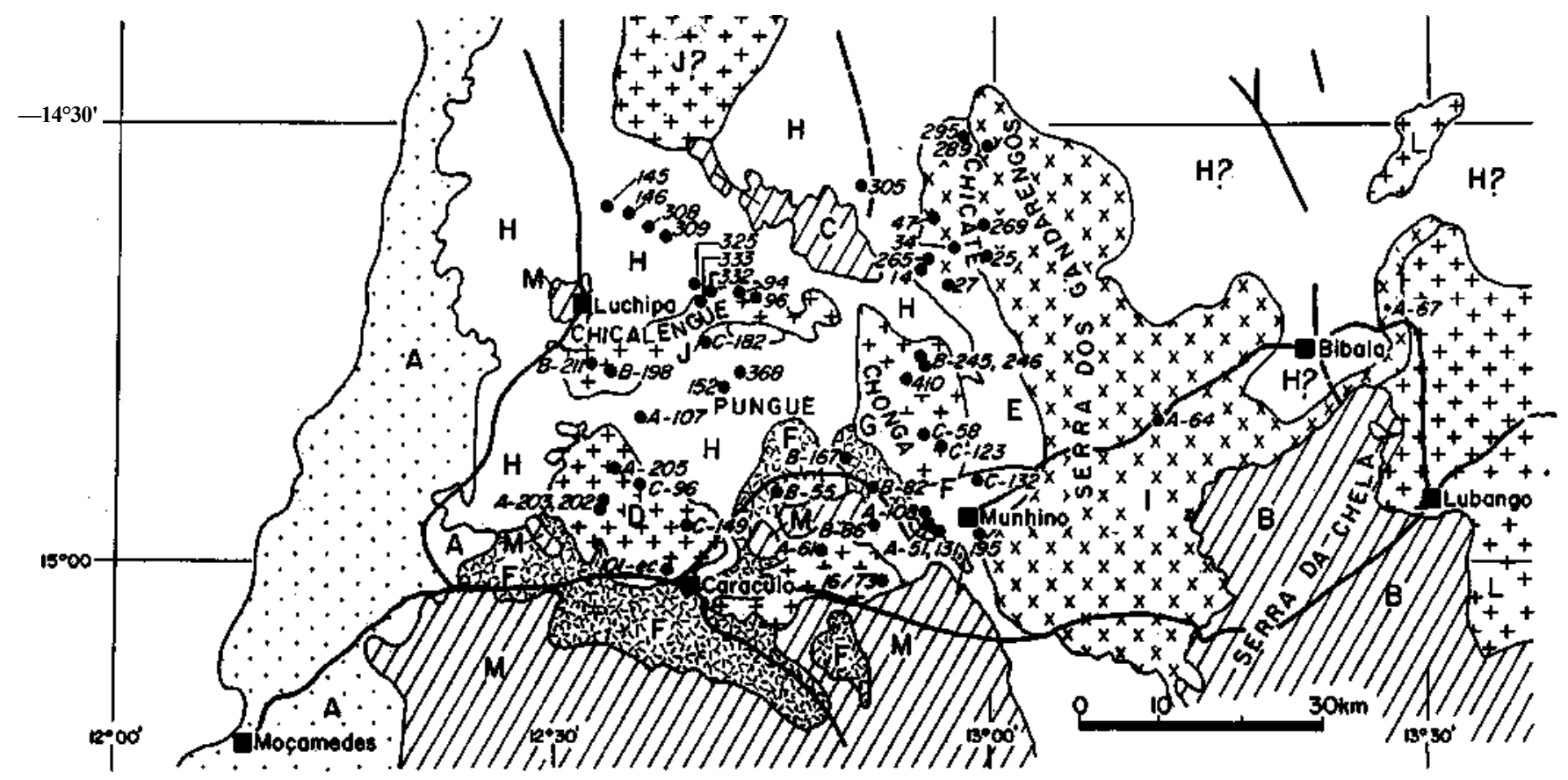

Figura 1 - Esboço geológico da Região de Caraculo-Bibala (extraído de Carvalho 1970, Carvalho 1982 e 1'orqualo \& Carvalho (em preparação). A. Seqüências Fanerozóicas; B. Supergrupo da Cheia; C. Metassedimenlos de Eque-Chicailungo; D. Granitóide do Caraculo; E. Granitóide do Chicote; F. Complexo Granítico do Munhino; G. Granitóide da Chonga; H. Complexo Granítico de Luchipa-Pungue; I. Granitóide dos Gandarengos; J. Granitóide de Chicalengue; L. Granitóide "regional"; M. Complexo xisto-quartzitico-anfibolítico com mármores associados

Figure 1 -GeologicaloutlineofCaraculo-BibalaRegion(CompiledfromCarvalho 1970;Carvalho 1982;Torquato\&Carvalho(inprep.) A. PhanerozoicSequences; B. Chela Supergroup; C. Eque-Chicailungo Metassediments; D. Caraculo Granitoid; E.Chicate Granitoid; F. Munhino Granitic Complex; G. Chonga Granitoid; H. Luchipa Pungue Granitic Complex; I. Gandarengos Granitoid; J. Chicalengue Granitoid; L. Regional Granitoids; M. Supracrustals Sequences with Marbles

contato, formando aureolas nas quais as rochas predominantes são dioritos e granodioritos com hornblenda.

Nas regiões de contato com os mármores, o Granitóide de Caraculo origina granadas do tipo andradita, formando porções bastante enriquecidas nesse mineral.

Barros et al. (1964) caracterizaram geoquimicamente esse granitóide como predominantemente do tipo cálcio-alcalino, embora existam também termos de transição para o tipo alcalino.

MAGMATISMO BÁSICO Apesar do objetivo principal deste trabalho ser o de estudar o magmatismo granítico da região de Caraculo-Bibala, devido à grande quantidade de rochas básicas e ultrabásicas existentes na área, cabem aqui algumas considerações a respeito.

O magmatismo básico-ultrabásico na região ocorre sob a forma de diques de noritos e doleritos e de maciços básicos a ultrabásicos.

Os diques de noritos e diabásios são muito abundantes no sudoeste de Angola, estendendo-se desde a Namíbia até a região de Benguelaem Angola numa extensão de cerca de 500 $\mathrm{km}$. Esses diques, quando ocorrem na região dos sedimentos do Grupo da Cheia, originam 5/7/5 de grandes dimensões (Carvalho et al. 1987 e Carvalho \& Alves 1990).

A direção predominante dos enxames de diques máficos é $\mathrm{N}-\mathrm{S}$, com variações para $\mathrm{N} 30^{\circ} \mathrm{W}$. Mineralogicamente, tais rochas são compostas por labradorita, piroxênio e anfibólio dispostos numa textura de granular a ofítica.

Em geral, as rochas básico-ultrabásicas são constituídas por gabros, piroxenitos e hornblenditos, sendo os termos mais básicos constituídos por piroxenito anfibolítico composto mineralogicamente por piroxênios, hornblenda e olivina (Carvalho 1970).

Nas zonas de contato dessas rochas com o complexo gnáissico-migmatítico-granítico, são observadas brechas eruptivas formadas por fragmentos de material básico envolvidos por material granítico.

PRÇCEDIMENTOS ANALÍTICOS As dosagens quantitativas de $\mathrm{Rb}$ e $\mathrm{Sr}$ foram realizadas por fluorescência de Raios X, para as amostras com teores entre 50 e 500 ppm. As amostras com teores fora desse intervalo foram dosadas por diluição isotópica com traçadores enriquecidos em ${ }^{87} \mathrm{Rb} \mathrm{e}^{87} \mathrm{Sr}$.

A separação do $\mathrm{Sr}$ foi feita com colunas de troca iônica, em meio clorídrico, segundo as técnicas descritas em Kawashita (1972). A composição isotópica do $\mathrm{Sr}$ foi medida em espectrômetro de massa Micromass VG354, com cinco coletores.

Todos os valores de ${ }^{87} \mathrm{Sr} /{ }^{86} \mathrm{Sr}$ foram normalizados para o valor de ${ }^{88} \mathrm{Sr} /{ }^{86} \mathrm{Sr}$ igual a 0,1194 . No período dessas análises de $\mathrm{Sr}$, foram medidos o padrão interno S-10 e o padrão internacional NBS-987, obtendo-se os seguintes resultados:

$$
\begin{array}{cc}
\text { S-10 } & \text { NBS-987 } \\
1,29821 & 0,71025 \pm 0,00004 \\
1,28400 & \text { (média }-24 \text { medidas) }
\end{array}
$$

Para os cálculos das idades isocrônicas aqui apresentadas, foi utilizado o programa desenvolvido por Willianson (1968); a constante de desintegração do Rb empregada foi 1,42 $\times 10^{\prime_{11}}$ anos ${ }^{\prime \prime}$.

Para as medidas K-Ar, a dosagem de $\mathrm{K}$ foi feita por espectrofotometria de chama e as medidas isotópicas de Ar, realizadas em um espectrômetro de massa de fonte gasosa Nuclide tipo Reynolds MS-1, conforme técnicas descritas em Amaral et al. (1966).

As constantes utilizadas nos cálculos das idades $\mathrm{K}-\mathrm{Ar}$ foram as seguintes:

$$
\begin{aligned}
& \lambda_{\beta=}=4,962 \times 10^{-10} \cdot \text { anos }^{-1} \quad \%{ }^{40} \mathrm{~K} \text { em K} \mathrm{K}^{\text {lotal }}=0,01167 \\
& \lambda_{q}=0,581 \times 10^{-10} \text { anos }^{-1}
\end{aligned}
$$


DISCUSSÃO DOS RESULTADOS GEOCRONO-

LOGICOS A tabela 1 apresenta 47 dados analíticos RbSr em rocha total relativos ao magmatismo granítico da região de Caraculo-Bibala, sudoeste de Angola, sendo 42 realizados neste trabalho, duas constantes em Torquato \& Carvalho (em prep.) e três ainda inéditos, efetuados por $\mathrm{H}$. Carvalho e Y. Vialette nos Laboratórios daUniversité BlaisePascal - CNRS em Clermont-Férrand, França. A localização geográfica das amostras datadas consta da figura 1.

Os dados geocronológicos, quando tratados em diagramas isocrônicos, permitiram caracterizar três intervalos de idades distintas para a atividade granítica da área, que são: 1.950 $1.900 \mathrm{Ma}, 1.750-1.650 \mathrm{Ma}$ e 1.550-1.500 Ma. Idades dessa ordem, com exceção feita ao intervalo mais jovem, já foram encontradas em outras regiões de Angola por diversos autores, estando sintetizadas em Carvalho (1984).

As idades entre 1.800 - $1.650 \mathrm{Ma}$, na região sudoeste de Angola, foram relacionadas por Torquato (1974a) a um evento termotectônico denominado de Namib, posteriormente extendido para o norte de Angola e noroeste daNamíbia em forma de cinturão por Carvalho (1984) e agora denominado por Torquato \& Carvalho (em prep.) de Cinturão Curoca, de características orogênicas.

O primeiro intervalo de idades entre 1.950 e 1.900 Ma não está muito bem caracterizado geocronologicamente na área, sendo representado apenas pela colocação do maciço granítico do Chicalengue.

As amostras deste granitóide, analisadas por radiometria, apresentaram-se muito homogêneas quanto à razão $\mathrm{Rb} / \mathrm{Sr}$ e, consegüentemente, com distribuição espacial segundo o eixo

${ }^{87} \mathrm{Rb} /{ }^{86} \mathrm{Sr}$ do diagrama isocrônico muito restrita. Estas amostras delinearam, neste diagrama, uma reta com inclinação relativa a idade aproximada de $1.900 \mathrm{Ma}$, com razão inicial de 0,7016 (Fig. 2). O valor calculado para esta isócrona é de $1.970 \pm 119$ Ma e razão inicial de $0,7015 \pm 0,0014$.

Apesar do elevado erro obtido, podemos considerar este granitóide como formado no final da orogenia Transamazônica, por volta de $1.900 \mathrm{Ma}$, a partir de material diferenciado do manto superior ou produzido por fusão de crosta continental inferior severamente empobrecida em $\mathrm{Rb}$, a qual foi diferenciada do manto pouco tempo antes, dentro do próprio ciclo Transamazônico.

A amostra de número de campo 333, situada abaixo da isócrona traçada na figura 2 , sugere a possibilidade de se encontrarem granitos mais jovens, no maciço deChicalengue.

Dentro do intervalo de tempo $1.750-1.650 \mathrm{Ma}$, ocorreu a formação do Complexo Granítico Luchipa-Pungue e dos granitóides da Serra da Chonga e dos Gandarengos. As amostras relativas ao Complexo Luchipa-Pungue, quando tratadas em diagrama isocrônico $\mathrm{Rb}-\mathrm{Sr}$, definiram isócrona com inclinação relativa a idade de $1723 \pm 35 \mathrm{Ma}$, com relação inicial de 0,7075 $\pm 0,0003$ (Fig. 3).

Esta idade caracteriza a época principal de formação deste complexo granítico, podendo incluir rochas formadas pouco tempo antes ou pouco tempo depois.

$\mathrm{O}$ elevado valor obtido para a razão inicial de $\mathrm{Sr}$ sugere que os magmas parentais deste complexo granítico tiveram contribuição importante de material proveniente da crosta continental superior.

Para o Granitóide da Serra da Chonga foram analisadas cinco amostras pelo método $\mathrm{Rb}-\mathrm{Sr}$, cujos pontos analíticos, quando lançados em diagrama isocrônico, situaram-se próximos à reta da idade de $1.684 \pm 31 \mathrm{Ma}$, com razão inicial de $0,7065 \pm 0,0006$ (Fig. 4). Esta idade pode ser considerada como próxima da época de formação desse maciço.

$\mathrm{O}$ valor obtido para a razão inicial, por volta de 0,706 , sugere que grande parte do magma parental do Granitóide da Serra da Chonga derivou-se por processos de fusão parcial de crosta continental, com razão $\mathrm{Rb} / \mathrm{Sr}$ moderada. Ainda sobre este granitóide, deve ser assinalado que sua curva de evolução isotópica de $\mathrm{Sr}$ tem alta inclinação, o que é típico de rochas com variedades litológicas bastante diferenciadas (Fig. 9).

Os dados analíticos $\mathrm{Rb}$-Sr relativos às amostras provenientes do Granitóide da Serra dos Gandarengos definiram isócrona com idade de $1.757 \pm 42$ Ma e relação inicial de $0,7074 \pm$ 0,0004 (Fig. 5). Esta idade deve ser considerada como a época de formação destas rochas.

$\mathrm{O}$ valor elevado obtido para a razão inicial sugere que, a exemplo dos outros granitoides formados nesse intervalo de tempo, os magmas que originaram o granitóide tiveram importante contribuição de materiais provenientes da fusão parcial da crosta continental, diferenciada do manto superior em épocas anteriores a $1,9 \mathrm{Ga}$, como pode ser visto pela regressão da linha de evolução isotópica do Sr até o campo do manto (Fig. 9).

Cumpre assinalar, portanto, que o magmatismo granítico gerado entre 1.760 e 1.650 Ma apresenta valores de razão inicial ${ }^{87} \mathrm{Sr}{ }^{86} \mathrm{Sr}$ próximos a 0,707 , sugerindo a participação de materiais produzidos por refusão da crosta continental superior em seus respectivos processos de formação.

O período mais jovem de atividade magmática granítica compreende o intervalo de tempo entre 1.550 e $1.500 \mathrm{Ma}$, representado pelos granitóides do complexo Munhino, do Chicate e do Caraculo, cujas idades e razões iniciais são similares dentro dos erros analíticos, apesar de constituírem corpos distintos.

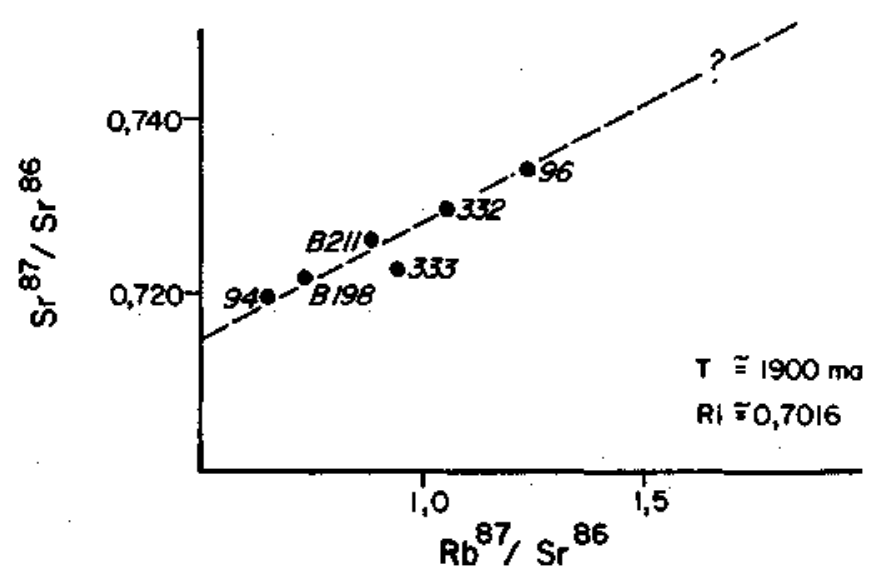

Figura 2 - Diagrama isocrônico $\mathrm{Rb}$ - Sr em rocha total para o Granitóide do Chicalengue

Figure 2 - Whole-Rock Rb - Sr isochronic diagram of the Chicalengue granitoid

As amostras relativas ao Complexo Granítico Munhino, analisadas pelo método $\mathrm{Rb}-\mathrm{Sr}$, situaram-se próximas a isócrona relativa a idade de $1.552 \pm 32 \mathrm{Ma}$, com razão inicial de 0,7057 $\pm 0,0003$ (Fig. 6). Alguns pontos analíticos a situaram pouco acima ou pouco abaixo da reta, o que sugere que podem possuir idades distintas daquela considerada; isso é normal dentro de um complexo granítico no qual as diferentes fácies litológicas presentes não são necessariamente sincrônicas. De uma forma geral, a idade de $1.552 \mathrm{Ma}$ pode ser considerada como a época principal de formação para o Complexo Munhino.

$\mathrm{O}$ valor darazão inicial sugere que a fonte desses granitóides é predominantemente crustal. A linha de evolução isotópica de Sr do complexo, na figura 9, inicia-se sobre a curva de evolução do Granitóide do Chicalengue, mostrando que rochas de composição similar a este granitóide foram também fundidas parcialmente durante o processo de formação de pelo menos parte dos granitóides do complexo Munhino.

Portanto, os Complexos Graníticos do Munhino diferem do Luchipa-Pungue nos tipos litológicos predominantes, na idade sendo mais jovem, e na natureza de suas fontes magmáticas, uma vez que foi formado em níveis crustais mais profundos.

Para o Granitóide do Caraculo, Torquato \& Carvalho (em 


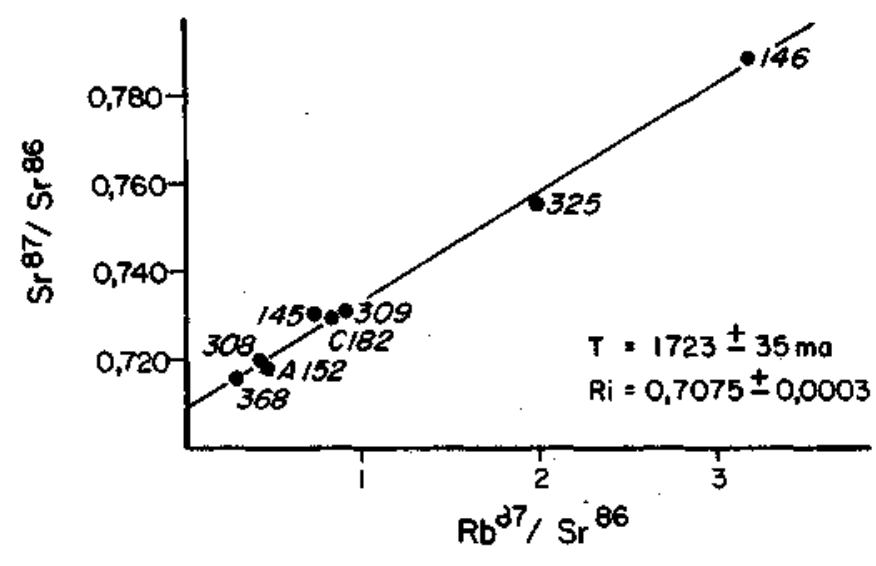

Figura 3 - Diagrama de evolução isotópica de Sr para o magmatismo granítico da região de Caraculo-Bibala. 1. Serra dos Gandarengos; 2. Luchipa-Pungue; 3. Caraculo; 4. Serra da Chonga; 5. Munhino; 6. Chicalengue; 7. Chicate; 8. Campo relativo ao Complexo Costeiro (Brasil)

Figure 3 - Whole-Rock Rb - Sr isochron of the Luchipa-Pungue granitic Complex

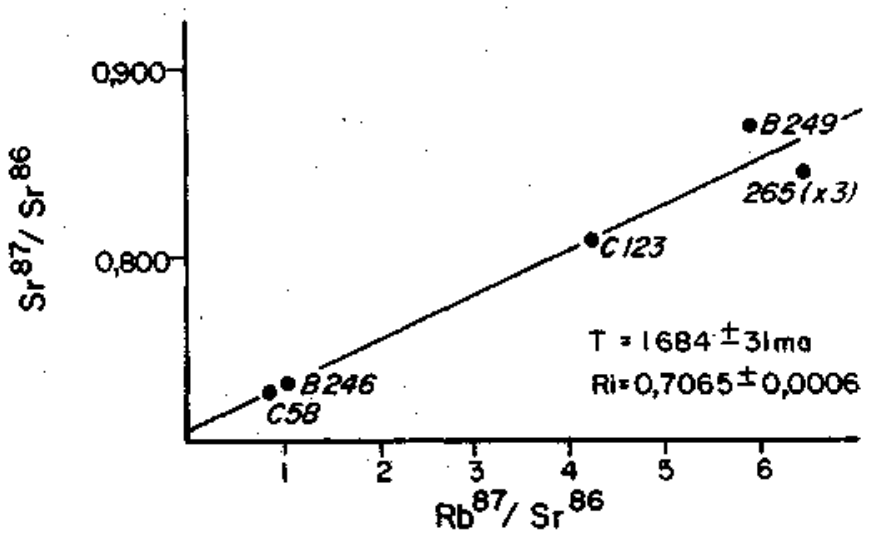

Figura 4 - Diagrama isocrônico $\mathrm{Rb}$ - Sr em rocha total para o Complexo Granítico Luchipa-Pungue

Figure 4 - Whole-Rock Rb -Sr Isochron for the Serra da Chonga granitoid

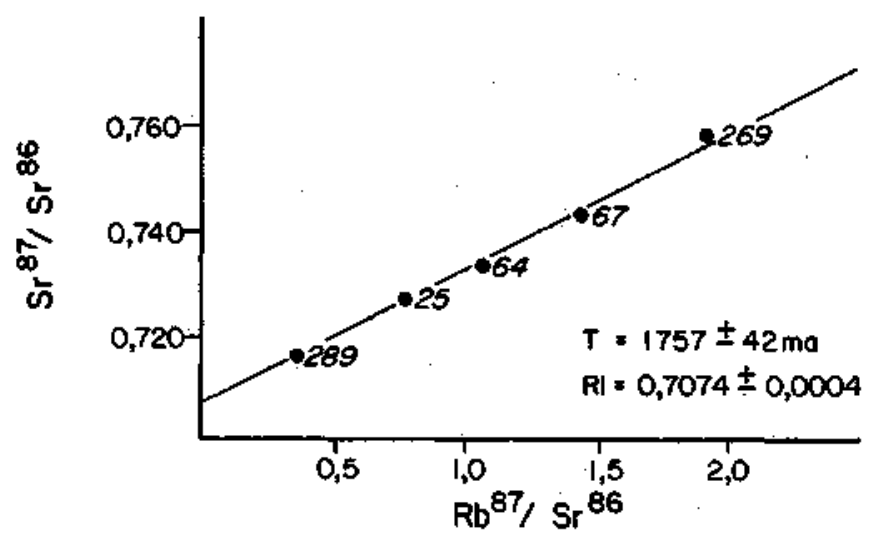

Figura 5 - Diagrama isocrônico $R b$ - Sr em rocha total para o Granitóide da Serra da Chonga

Figure 5 - Whole-Rock Rb - Sr isochronic diagram for Serrados Gandarengos granitoid prep.) apresentaram isócrona $\mathrm{Rb}-\mathrm{Sr}$ na qual incluíram pontos analíticos relativos a amostras provenientes da borda sul do Maciço, de pórfíros ácidos e granitos associados, obtendo a idade de $1.684 \pm 69 \mathrm{Ma}$, com razão inicial ${ }^{87} \mathrm{Sr}{ }^{86} \mathrm{Sr}$ de 0,7034 . Neste trabalho, foi elaborada isócrona $\mathrm{Rb}-\mathrm{Sr}$ com amostras coletadas nas porções central e norte-nordeste do Maciço do Caraculo. Nela foram adicionados somente os pontos de Torquato \& Carvalho (em prep.) situados na borda sul do corpo, sendo obtida a idade de $1.510 \pm 25 \mathrm{Ma}$, com razão ${ }^{87} \mathrm{Sr} /$ ${ }^{86}$ Sr inicial de $0,7048 \pm 0,0012$ (Fig. 7).

A idade próxima a 1.500 Ma é interpretada como a época de formação de pelo menos parte do Granitóide do Caraculo.

A diferença entre as idades obtidas pode sugerir que os pórfíros ácidos e granitos associados não são sincrônicos ao corpo do Caraculo ou que este maciço, na verdade, constituise de um complexo granítico com evolução não-sincrônica, sendo as porções central e norte-nordeste as mais jovens.

O valor obtido para a razão inicial, de 0,7048 , é baixo, sugerindo que os magmas formadores deste granitóide derivaram-se principalmente de fusões de rochas com baixas ou moderadas razões $\mathrm{Rb} / \mathrm{Sr}$ típicas da crosta continental inferior ou intermediária. As amostras do Granitóide do Caraculo apresentam um trend de diferenciação bastante acentuado, conforme pode ser observado na figura 10 , sugerindo que as

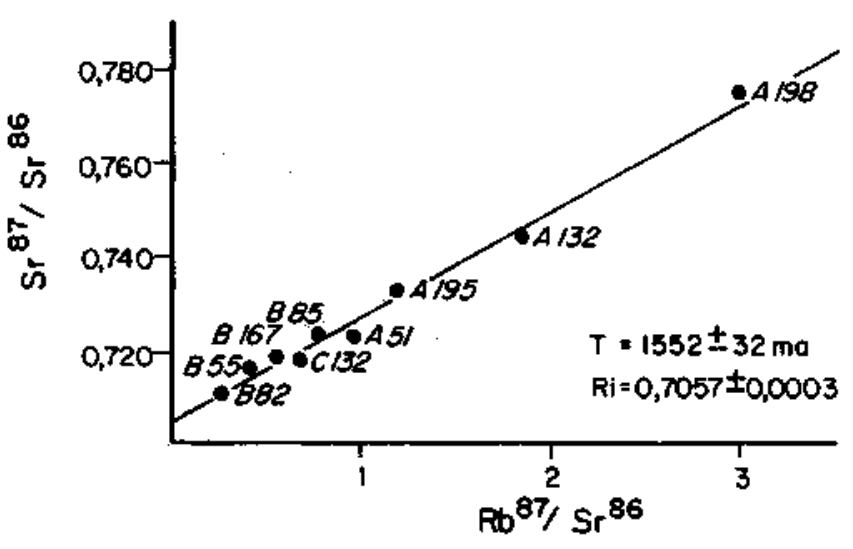

Figura 6 - Diagrama isocrônico Rb - Sr em rocha total para o granitóide da Serra dos Gandarengos

Figure 6 - Whole-Rock Rb - Sr Isochron of the Munhino granitic Complex

rochas co-magmáticas do maciço apresentam uma grande variação composicional.

O Maciço Granítico de Chicate apresentou idade isocrônica de $1.527 \pm 40 \mathrm{Ma}$ e razão ${ }^{87} \mathrm{Sr} /{ }^{86} \mathrm{Sr}$ inicial de $0,7053 \pm 0,0005$ (Fig.8). Esta idade é interpretada como a da época de formação deste granitóide; o valor próximo a 0,705 da razão inicial indica que essas rochas evoluíram principalmente a partir de processos de fusão parcial de rochas crustais pouco diferenciadas geoquimicamente.

É importante notar que os granitóides gerados no episódio magmático mais jovem, entre 1.550 e $1.500 \mathrm{Ma}$, possuem razões iniciais muito similares, mostrando que este magmatismo, embora formando corpos distintos geograficamente, além de contemporâneo, foi formado pelos mesmos processos e com protolitos de mesma natureza.

Nos diagramas das figuras 9 e 10, é possível observar que os granitóides do Caraculo, Munhino e Chicate, apesar de contemporâneos e com fontes similares, apresentam graus de diferenciação diferentes, com o corpo do Caraculo incluindo os termos mais diferenciados, conseqüentemente apresentando a linha de evolução isotópica de Sr mais inclinada (Fig. 9) 


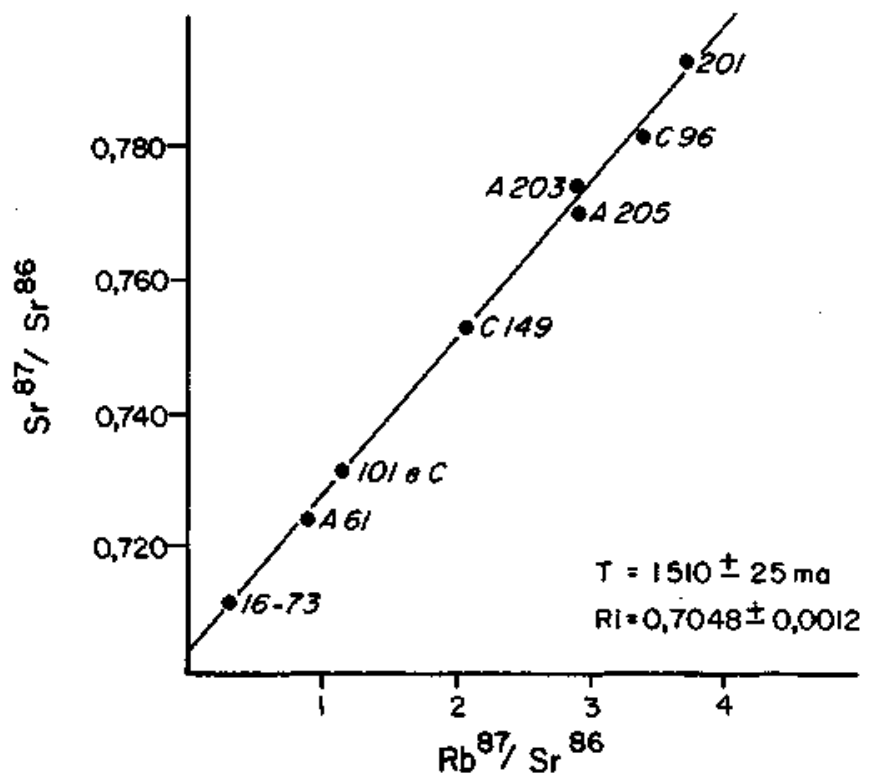

Figura 7 - Diagrama ${ }^{87} \mathrm{Sr}^{86}$ versus $\mathrm{Sr}$ total para o magmatismo granítico da região de Caraculo-Bibala

Figure 7 - Whole-Rock Rb - Sr Isochron of the Caraculo granitoid

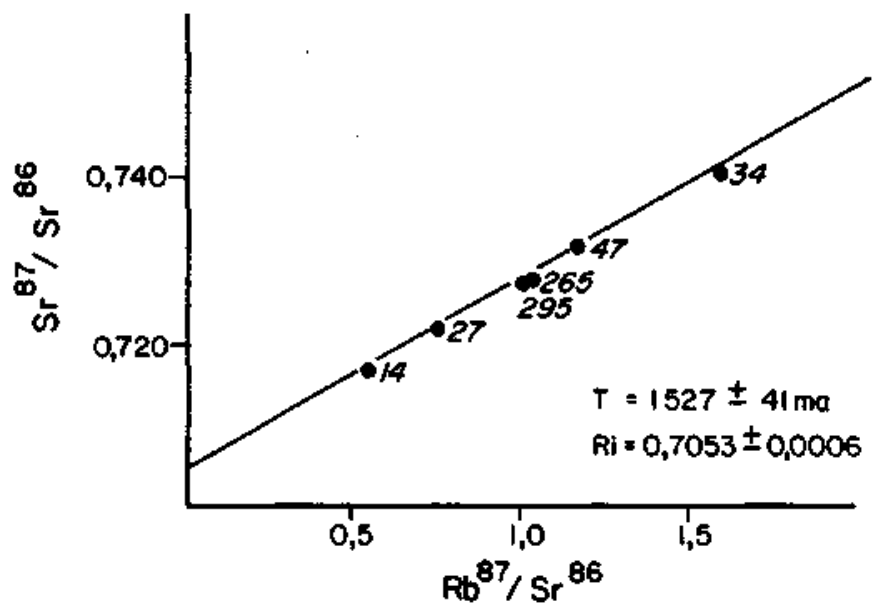

Figura 8 - Diagrama Isocrônico $\mathrm{Rb} / \mathrm{Sr}$ em rocha total para $n$ Complexo Granítico de Munhino

Figure 8 -Wholw-Rock Rb - Sr Isochron of the Chicate granitoid

e um trend mais amplo no diagrama da figura 10. Esse fato poderia sugerir níveis crustais distintos de colocação destes maciços.

$\mathrm{Na}$ região de Caraculo-Bibala, em meio aos granitóides, ocorrem rochas básicas em forma de diques, sills e pequenas intrusões. Duas amostras deste magmatismo foram datadas pelo método K-Ar, uma relativa aos diques (amostra $\mathrm{n}^{2} 305$ ) e outra relacionada aos sills (amostra A-107), cujos dados analíticos encontram-se na tabela 2 . A primeira amostra indicou a idade $698 \pm 11 \mathrm{Ma}$ e a segunda $600 \pm 8 \mathrm{Ma}$.

Idades K-Ar desta ordem, dentro do intervalo de tempo 820$650 \mathrm{Ma}$ já foram encontradas para o magmatismo básico de outras áreas da região sudoeste de Angola por Torquato \& Amaral (1973), Silva et al. (1973), Torquato (1974a e b) e Silva (1980).

As idades K-Ar, entre 700 e 600 Ma, são consideradas como mínimas para este magmatismo básico. Esta interpretação baseia-se no fato de rochas básicas de mesmo contexto geológico, situadas mais a sul, possuírem idade isocrônica $\mathrm{Rb}$-Sr em rocha total de $1.119 \pm 27 \mathrm{Ma}$, com razão inicial de

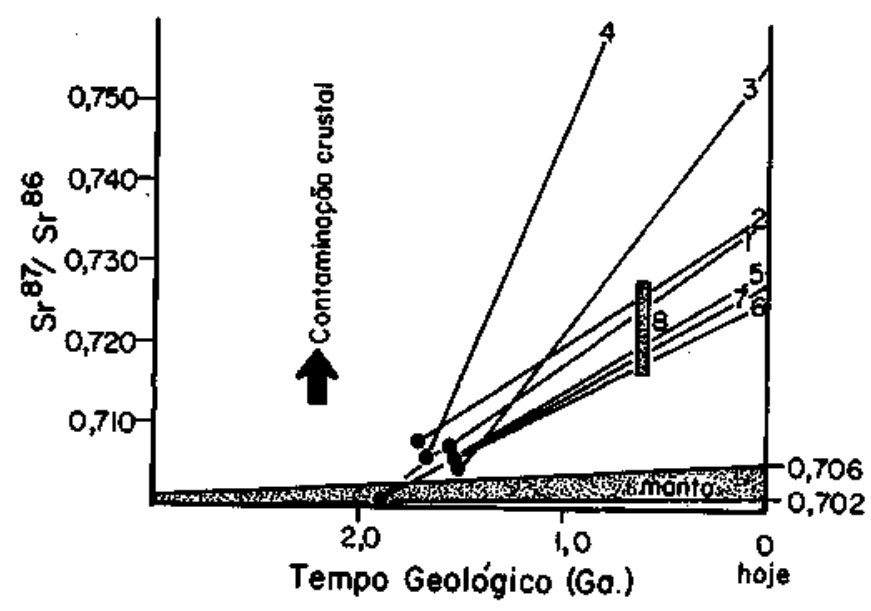

Figura 9 - Diagrama Isocrônico $\mathrm{Rb}$ - Sr em rocha total para o granitóide de Caraculo

Figure 9 - Sr Isotopic Evolution for the granitic magmatism. 1. Serra dos Gandarengos; 2. Luchipa-Pungue; 3. Caraculo; 4. Serra da Chonga; 5. Munhino; 6. Chicalengue; 7. Chicate; 8. Costeiro Complex Sr isotopic composition

0,7044 (Carvalho et al. 1987), interpretada como a época de formação destas rochas, e também por existirem idades K-Ar em biotitas de $774 \pm 16 \mathrm{Ma}$ (Torquato \& Carvalho, em prep.) e Rb-Sr em biotitas de $551 \pm 30$ Ma (Mendes 1968) nos granitóides do Proterozóico Médio da área em estudo.

Portanto, as idades entre 850 e 600 Ma obtidas nas rochas básicas foram interpretadas neste trabalho como idades aparentes, rejuvenescidas termicamente pela orogênese DamaraRibeira, esta última na área contígua do lado brasileiro, durante o Proterozóico Superior.

\section{RELAÇÕES DO MAGMATISMO GRANÍTICO COM AS SEQÜÊNCIAS METASSEDIMENTARES Na} região do Complexo Granítico Luchipa-Pungue existem diversos tipos de rochas metassedimentares, de idades também diferentes.

A ocorrência de rochas metassedimentares situadas a norte de Pungue (Fig. 1), no contato entre o complexo granítico e o Granitóide do Chicalengue, possui direção aproximada E$\mathrm{W}$, sendo essencialmente constituída por conglomerados e quartzitos. Os conglomerados são formados por pequenos clastos de quartzito que dificilmente se distinguem da matriz de quartzo microgranular.

Nos quartzitos que ocorrem junto do Granitóide do Chicalengue, observam-se fenômenos de metamorfismo de contato que se manifestam principalmente pela presença de numerosos cristais de feldspato (Carvalho 1970).

Esta seqüência metassedimentar é intrudida por pórfíros quartzo-feldspáticos e vulcânicas associadas com 2.200 Ma, o que lhe confere idade mínima (Carvalho \& Alves 1990).

As rochas metassedimentares da seqüência situada a norte de Pungue depositaram-se após intenso período de erosão das rochas do Complexo Xisto-Quartzítico-Anfibolítico com mármores associados, e estão afetadas pelo Granitóide do Chicalengue.

Desse modo, essa ocorrência teria idade situada entre a do Complexo Xisto-Quartizítico-Anfibolítico com mármores associados e a do Granito do Chicalengue, isto é, entre 2.200 e $1.950 \mathrm{Ma}$.

A nordeste do Complexo Granítico Luchipa-Pungue, existem grandes ocorrências de rochas metassedimentares essencialmente formadas por camadas suborizontais de conglomerados e quartzitos, às quais se associam sills e diques de vários tipos de rochas vulcânicas (Carvalho 1970).

Os conglomerados ocorrem, em regra, na base da seqüência 


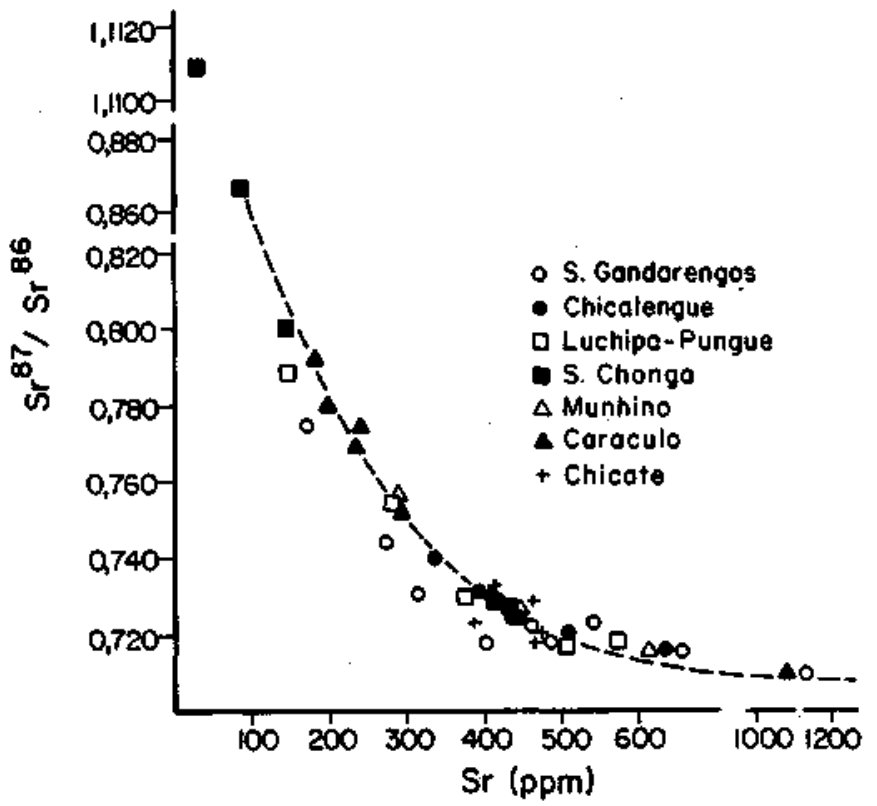

Figura 10-Diagrama isocrònico Rb - Sr em rocha total para o granitóide de Chicate

Figure $10^{-87} \mathrm{Sr}{ }^{86} \mathrm{Sr}$ versus $\mathrm{Sr}$ diagram for the granitic magmatism of the

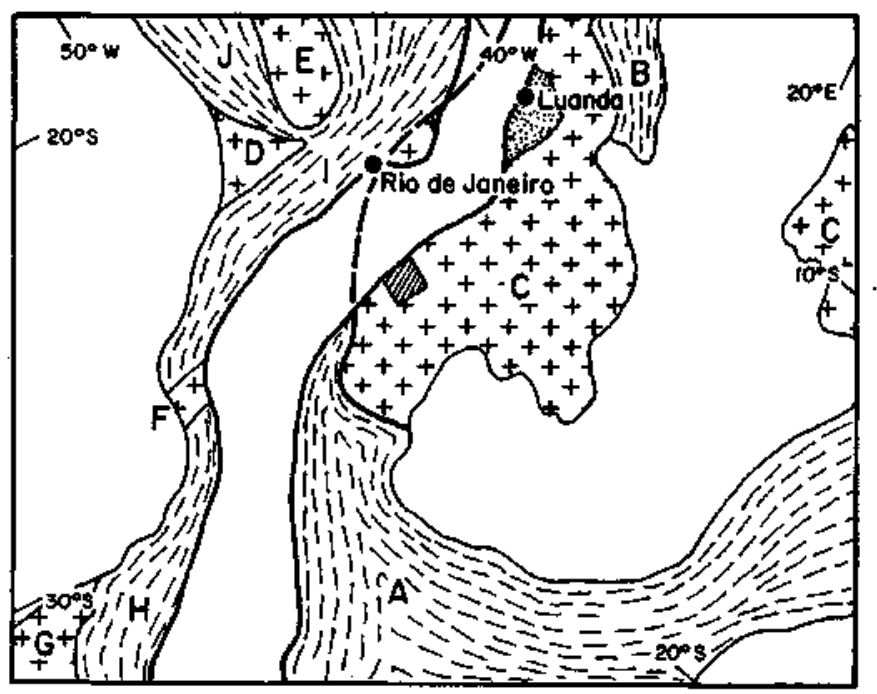

Caraculo-Bihala re» ion

Figura 11 - Correlação geocronológica Angola-Brasil. A. Cinturão Domara; B. Cinturão Oeste-Congo; C. Craton Angola-Kasai; D. Maciço de Guaxupé; E. Craton São Francisco; F. Craton Luiz Alves; G. Craton Rio de La Plata; H. Cinturão Dom Feliciano; I. Cinturão Ribeira; J. Cinturão Brasília; R. J. Rio de Janeiro; L. Luanda Figure 11 - Geochronological Correlation between Angola-Brasil. A. Damara Belt; B. West-Congo Belt; C. Angola-Kasai Craton; D. Guaxupé Massif; E. São Francisco Craton; F. Luiz Alves Craton; G.Rio de La Plata Craton; H. Dom Feliciano Belt; I. Ribeira Belt; J. Brasília Belt; R.J. Rio de Janeiro; L. Luanda

e são formados por clastos de quartzitos e de rochas granitóides. Estes últimos chegam a atingir cerca de $1 \mathrm{~m}$ de diâmetro e são macroscópicamente semelhantes aos do Complexo Granítico Luchipa-Pungue. A ocorrência dispõe-se segundo direção geral NW-SE e os metassedimentos apresentam, em geral, baixo grau de metamorfismo (muscovita).

A seqüência metassedimentar referida assenta em discordância sobre o Complexo Granítico Luchipa-Pungue e
Tabela 1 - Dados analíticos $\mathrm{Rb}$-Sr em rocha total

Table 1 - Analytical data for $\mathrm{Rb}-\mathrm{Sr}$ in whole rock

\begin{tabular}{|c|c|c|c|c|c|c|}
\hline UNIDADE & $\underset{\text { CAMPO }}{\mathrm{N}^{*}}$ & $\mathrm{Rb}(\mathrm{ppm})$ & Sr (ppm) & $87 \mathrm{Rb} / 86 \mathrm{Sr}$ & $87 \mathrm{Sr} / 86 \mathrm{Sr}$ & $N^{*}$ LAB \\
\hline \multirow{5}{*}{$\begin{array}{l}\text { GRANITOIDE } \\
\text { SERRA DOS } \\
\text { GANDARENGOS }\end{array}$} & 289 & 78 & 609 & 0.371 & 0.7168 .3 & 10955 \\
\hline & 25 & 123 & 4.50 & 0,793 & 0.72756 & 10906 \\
\hline & 269 & 194 & 293 & 1.926 & 0.75734 & 10906 \\
\hline & $67^{*}$ & • & - & I 43.18 & 074311 & - \\
\hline & $64^{*}$ & - & - & 1.085 & 0.75312 & . \\
\hline \multirow{8}{*}{$\begin{array}{c}\text { COAPLEXO } \\
\text { GRANÍTICO } \\
\text { LUCHIPA-PUNGUE }\end{array}$} & 368 & 71 & 656 & 0.313 & 0.71595 & 10957 \\
\hline & 308 & 89 & 573 & 0.450 & 0.71903 & 10963 \\
\hline & $A-152$ & 87 & 508 & 0.496 & 0.71768 & 10875 \\
\hline & 145 & 101 & 412 & 0.711 & 0.73039 & 10961 \\
\hline & $C .182$ & 111 & 377 & 0.858 & 0.72962 & 10874 \\
\hline & 309 & $\$ 25$ & 395 & 0.918 & $0+3031$ & 10964 \\
\hline & 325 & 192 & 281 & 1.987 & 0.75438 & 10965 \\
\hline & 146 & 163 & 150 & 3.170 & 0.78858 & 10962 \\
\hline \multirow{9}{*}{$\begin{array}{l}\text { COMPLEXO } \\
\text { GRANITICO } \\
\text { DO MUNHINO }\end{array}$} & B-82 & 103 & 1109 & 0.269 & 0.71096 & $10 \% 66$ \\
\hline & B-s5 & 100 & 708 & 0.409 & 0.71588 & 10952 \\
\hline & B-167 & $\pi$ & 406 & 0.507 & 0.71854 & 10913 \\
\hline & $C .132$ & $1: 2$ & 483 & 0.675 & 0.71880 & 10873 \\
\hline & B-86 & 145 & 541 & 0.777 & 072423 & 10954 \\
\hline & A.51 & 156 & 461 & $0.98 \mathrm{I}$ & 072345 & 10871 \\
\hline & A-195 & 128 & $3 / 3$ & 1191 & 0.73194 & 10862 \\
\hline & $A=132$ & 176 & 272 & 1885 & 0.74507 & 10372 \\
\hline & A. 198 & 180 & 174 & 3.022 & 077556 & 10863 \\
\hline \multirow{8}{*}{$\begin{array}{l}\text { GRANITÓADE } \\
\text { DO CARACULO }\end{array}$} & $16 / 73^{*=}$ & 118 & 1035 & 0316 & 0.71090 & 715 \\
\hline & $A \cdot 61^{*}$ & - & $\cdot$ & 0.924 & 0.72190 & $=$ \\
\hline & $101 / e c * 0$ & 159 & 410 & 1.130 & 0.73130 & 345 \\
\hline & $C+149$ & 238 & 293 & 2163 & 0.75298 & 10841 \\
\hline & A205 & 238 & 235 & 2.949 & 0.76905 & 10870 \\
\hline & A.203 & 244 & 242 & 2937 & 0.77411 & 10842 \\
\hline & c. $\%$ & 242 & 202 & 3.492 & 0.78010 & 10840 \\
\hline & A-202 & 240 & 185 & 3.786 & 0.79270 & 10869 \\
\hline \multirow{5}{*}{$\begin{array}{l}\text { GRANITÓIDE } \\
\text { DA SERRA } \\
\text { DO CHONGA }\end{array}$} & C-58 & 122 & 439 & 0806 & 0.72701 & 10914 \\
\hline & $C-123$ & 214 & 148 & 4.227 & 0.80938 & to9is \\
\hline & B-246 & 145 & 414 & 1.016 & 0.72922 & 30058 \\
\hline & B-249 & 168 & 4 & 5879 & 0.86700 & 10959 \\
\hline & 410 & 239 & 37 & 19.435 & $1.10 \times 94$ & 10960 \\
\hline \multirow{6}{*}{$\begin{array}{l}\text { GRANITÓIDE } \\
\text { CHICALENGUE }\end{array}$} & 94 & $10 ?$ & $46 ?$ & 0.667 & 0.71919 & 10866 \\
\hline & B-198 & 119 & 473 & 0729 & 0.72194 & 10964 \\
\hline & B-211 & 134 & 435 & 0.892 & 0.72752 & 10867 \\
\hline & 333 & 126 & 380 & 0.861 & 0.72298 & 10868 \\
\hline & 332 & 167 & 459 & 1.056 & 0.72980 & $1\} 240$ \\
\hline & 96 & 170 & 405 & 1.222 & 073397 & 10838 \\
\hline \multirow{6}{*}{$\begin{array}{l}\text { GRANITÓIDE } \\
\text { CHICATE }\end{array}$} & 27 & IנI & 507 & 0.749 & 0.72198 & 50909 \\
\hline & 34 & 184 & 332 & 1.609 & 0.74009 & $109 J 0$ \\
\hline & 47 & 157 & 398 & 1.174 & 0.73206 & 10911 \\
\hline & 14 & III & 633 & 0.508 & 0.51647 & 10956 \\
\hline & 265 & 151. & 431 & 1.029 & 0.7277 & 10912 \\
\hline & 295 & 351 & 430 & 1.018 & 0.72633 & 10908 \\
\hline
\end{tabular}

- Andilises ígedias feitas por Y. Vinilete e H. Carvatho-Clermom Ferrand - Franch

-" Torquato \& Carvalto fem preq.

Tabela 2 - Dados analiticos $K-A r$ Table 2 - Analytical data for $\mathrm{K}-\mathrm{Ar}$

\begin{tabular}{|c|c|c|c|c|c|c|c|}
\hline $\begin{array}{c}N^{\circ} \\
\text { AMOSTRA }\end{array}$ & ROCHA & MATERJAL & $\% x$ & $\begin{array}{l}\text { Ard0 rad } \\
\operatorname{ccSTP} / \mathrm{q}\end{array}$ & $\%$ Ar atm & $\begin{array}{c}\text { TDADE } \\
\text { (Ma) }\end{array}$ & $N^{*}$ LAB \\
\hline 305 & Dinbasio & Playioc. & 1776 & $58,75,10-6$ & 9.83 & $698+1-11$ & 6699 \\
\hline A- 107 & Dhatiso & K-Feld+Plsg & 3.819 & $106,08.10-$ & 6,72 & $600+f-8$ & 6700 \\
\hline
\end{tabular}


são intrudidos pelo Granitóide do Chicate (Carvalho 1984). Assim, a idade destes metassedimentos situam-se entre 1.720 e $1.530 \mathrm{Ma}$ aproximadamente.

As unidades metavulcanossedimentares, com idades entre 1.720 e $1.530 \mathrm{Ma}$, poderiam estar vinculadas à evolução do Cinturão Magmático, já caracterizado por Carvalho (1984) e Torquato \& Carvalho (em prep.), que teve sua evolução entre 1.800 e $1.650 \mathrm{Ma}$, com formação de granitos cálcio-alcalinos e processos de retrabalhamento crustal.

Cumpre assinalar que tais seqüências metassedimentares são cronocorrelatas com as formações metavulcanossedimentares que ocorrem na Faixa Apiaí, sudeste de São Paulo, para as quais Tassinari et al. (1990) estimaram uma época entre 1.750 e 1.500 Ma para a deposição das seqüências.

CORRELAÇÃO GEOLÓGICA COM A REGIÃO SUDESTE DO BRASIL A área contígua em território brasileiro da região angolana de Caraculo-Bibala corresponde a faixa situada aproximadamente entre as cidades de Caraguatatuba e Parati, nas regiões sudeste do Estado de São Paulo e sul do Rio de Janeiro.

Em contexto geotectônico, esta área está incluída nos domínios do Cinturão de Dobramentos Ribeira, que teve sua evolução durante o Proterozóico Superior, com suas fases sintectônicas variando desde 800 até $600 \mathrm{Ma}$, dependendo da região.

Geologicamente, esta área de correspondência inclui terrenos metamórficos de médio a alto grau do Complexo Costeiro e granitóides pós-tectônicos. O Complexo Costeiro é constituído por gnaisses migmatíticos, paragnaisses portadores de granadas e, subordinadamente, quartzitos, rochas cálciosilicatadas e metassedimentos síltico-argilosos. Este conjunto metamórfico encontra-se intrudido por vários corpos de granitóides porfiróides, por vezes foliados, de composição variável de granítica a granodiorítica, mas ocorrendo também variações alasquíticas, cálcio-alcalinas e alcalinas. Estes maciços graníticos estão, em geral, relacionados com corpos charnockíticos (granitos com "hiperstênio") de naturezaígnea.

Em termos geocronológicos, estudos realizados por Tassinari et al. (1988) indicaram idades isocrônicas $\mathrm{Rb}-\mathrm{Sr}$ em rocha total para os terrenos gnáissico-migmatíticos do Complexo Costeiro, obtidas para locais distintos, variáveis entre 650 a $600 \mathrm{Ma}$, com razões iniciais entre 0,709 e 0,727, sendo que, próximo à área de correspondência, os valores variam de 0,717 a 0,727 . Para os granitóides e charnockitos intrusivos, Tassinari et al. (1990) e Gasparini \& Mantovani (1975) forneceram idades, também isocrônicas $\mathrm{Rb}-\mathrm{Sr}$, no intervalo de tempo $550-500 \mathrm{Ma}$, com razões ${ }^{87} \mathrm{Sr} /{ }^{86} \mathrm{Sr}$ iniciais próximas a 0,712 .

Estes dados indicam claramente que os terrenos metamórficos e os granitóides intrusivos formaram-se respectivamente por retrabalhamento e anatexia de rochas da crosta continental superior, no final do Proterozóico Superior e no início do Fanerozóico. Tassinari et al. (1989) obtiveram também, para estas rochas, valores de $e_{N} d$ fortemente negativos, o que confirma, pelas composições isotópicas de $\mathrm{Nd}$, a hipótese de origem a partir da reciclagem de materiais crustais.

Em adição, estes autores obtiveram, para as mesmas rochas, idades Sm-Nd, modelo Manto Empobrecido (TDM), de 1,8 e 2,0 Ga, sugerindo o Ciclo Transamazônico como o principal evento formador dos protolitos crustais das rochas do Complexo Costeiro e dos granitóides intrusivos. Essas idades correlacionam-se temporalmente com as idades obtidas para o magmatismo granítico mais antigo da região angolana do Caraculo-Bibala e/ou para respectivas diferenciações mantélicas, dos protolitos dos outros granitóides.

Portanto, embora as idades de formação das rochas da região sudoeste de Angola e da área contígua no Brasil não se correlacionem diretamente, é muito provável que as rochas incluídas no Complexo Costeiro tenham sido geradas a partir de retrabalhamento, pela orogênese brasiliana, de terrenos similares aos existentes no sudoeste do Cráton de AngolaKasai, uma vez que tais terrenos são constituídos, além das rochas graníticas e gnáissicas, por expressivas seqüências de rochas metassedimentares e rochas básicas e ultrabásicas que, quando retrabalhadas, poderiam produzir as seqüências de paragnaisses granadíferos e os restos de rochas básicas e ultrabásicas metamorfizadas encontradas no Complexo Costeiro no Brasil.

No diagrama de evolução isotópica do $\mathrm{Sr}$ da figura 9, está representado o campo da variação de valores para as razões ${ }^{87} \mathrm{Sr} /{ }^{6} \mathrm{Sr}$ iniciais das rochas metamórficas do Complexo Costeiro^ ${ }^{\wedge}$ próximosàáreade correspondência. Pode ser observado que este campo situa-se sobre as curvas de evolução isotópica de $\mathrm{Sr}$ das rochas graníticas da região de Caraculo-Bibala, sugerindo a possibilidade de rochas similares a estas constituírem as fontes de pelo menos parte dos terrenos do Complexo Costeiro.

A figura 11 representa a correlação geológica BrasilAngola, onde se observa que a orogenia brasiliana, representada na África pelo Cinturão Damara, ocorre somente no extremo sudoeste de Angola e depois inflete-se para oeste, ocorrendo no Brasil no Cinturão de Dobramentos Ribeira, que se estende para norte, amalgamando os Crátons do São Francisco e de Angola-Kasai.

Portanto, a área estudada neste trabalho situa-se nas bordas do Cráton de Angola-Kasai, onde a orogênese brasiliana apenas produziu eventos térmicos, que rejuvenesceram idades K-Âr, mas não formou rochas, ao passo que, na área contígua no Brasil, esta orogênese foi muito intensa, gerando grande quantidade de rochas metamórfícas que atingiram até a fácies granulito e forte magmatismo granítico. Apenas na região de Cabo Frio, a nordeste da cidade do Rio de Janeiro, foi identificado um pequeno núcleo preservado com idades transamazônicas (Zimbres et al. 1990), que seria um pequeno fragmento do Cráton Angola-Kasai, que ficou do lado brasileiro, conforme pode ser observado na figura 11 .

Agradecimentos Os autores agradecem, no Brasil, ao Conselho Nacional de Desenvolvimento Científico e Tecnológico (CNPq) e, em Portugal, ao Instituto de Investigação Científica Tropical, pelo apoio financeiro que possibilitou o intercâmbio que gerou este trabalho. Agradecem também aos técnicos do Centro de Pesquisas Geocronológicas da Universidade de São Paulo e do Instituto de Investigação Científica Tropical (Lisboa), pelo auxílio prestado durante o desenvolvimento desta pesquisa. Agradecem à Fundação de Amparo à Pesquisa do Estado de São Paulo (FAPESP), pela concessão de bolsa de Iniciação Científica (Processo 90/15948), e à bolsista Annabel Perez Aguilar, pelo auxílio durante as fases analíticas. Os agradecimentos são extensivos aos geólogos de Seviço de Geologia e Minas de Angola, pelo incentivo dado a este projeto.

\section{REFERÊNCIAS BIBLIOGRÁFICAS}

ALVES, C.A.M.\& MACEDO, J.R. 1965. Petrografia da região do Munhino (áreade Caraculo, distrito de Moçàmedes). 2. Rochas do complexo granítico. Garcia Orta, 13(2):259-266.

AMARAL, G.; CORDANI, U.G.; KAWASHITA, K.; REYNOLDS, J.H 1966. Potassium-Argon dates of basaltic rocks from southern Brazil. Geoch. Cosmoch. Acta, 30:159-189.
BARROS,L.A.;ALVES,C.M.; MACEDO, J.R. 1964. Petrografia da região de Munhino (folha 334 da carta de Angola) 1. Granitos. Garcia Orta., 12(2):355-364.

CAHEN, L.; SNELLING, N.J.; DELHAL, J.; VAIL, J.R. 1984. The geochronology and evolution of Africa. Oxford, Clarendon Press. 512 p. (Col. BONHOMME, M. \& LEDENT, D.). 
CARVALHO, H. 1970. Estudos geológicos da região de Munhino (Caraculo), no sudoeste de Angola. Luanda. Inst. Invest. Cient. Angola, 48 p. [Boletim 7(1)]

CARVALHO, H. 1982. Mapa Geológico de Angola. Lisboa, Inst. de Invest. Cientif. Tropical. (Folhas 1, 2,3,4).

CARVALHO, H. 1984. Estratigrafia do Pré-Câmbrico de Angola. Garcia Otó, 7(1-2):1-66

CARVALHO, H. \& ALVES, P. 1990. Gabbro-Anorthosite Complex ofSW Angola/NW Namibia. Lisboa, Inst. Inv. Cient. Tropical. 65 p. (Ser. Ciências da Terra, Com. 2).

CARVALHO, H.; CRASTO, J.P.; SILVA, Z.C.G.; VIALETTE, Y. 1987. The Kibaran cycle in Angola-a discussion. Geo/.J., 22:85-102 (Thematic Issue).

DELHAL, J.;LEDENT,D.;PASTELS,P. 1915.L'ageducomplexegranitique etmigmatitic de Dibaya (regiondu Kasai, Zaire)par lês méthodes Rb-Sr et U-Pb. Ann. Soe. Géol. Belg., 98: 141-154.

GASPARINI, P \& MANTOVANI, M .S.M. 1979. Geochemistry of chamockites from São Paulo State, Brazil. Earth and Planet. Sei. Let., 42:311 -320.

KAWASHITA, K. 1972.0 método Rb-Sr em rochassedimentares, aplicação para as Bacias do Paraná e Amazonas. São Paulo. 111 p. (Tese de Doutoramento, IG/USP)

MENDES, F. 1968. Mesure Geochronologiques en Angola. France. 21 p. (Tese de Doutoramento, Univ. Cl. Ferrand).

SILVA, A.T.S. 1980. Idade Radiométrica K-Ar do dique norítico de Vila Arriaga e sua relação com o Grupo Cheia (Angola). Lisboa, Acad.Cien. p. 137-159. (Mem. 21).

SILVA, A.T.S.F.TORQUATO,J.R.; KAWASHITA, K. 1973. Algunsdados geocronológicos pelo método $K$-Ar da região de Vila Paiva, Couceiro, QuilengueseChicomba (Angola). Luanda, Ser. Geol. e Minas de Angola. p. 3-20 (Boletim 24).

TASSINARI, C.G.C; BARBOUR, A.P ; DAITX, E.C.; SATO, K. 1990 Aplicação dos isótoposde $\mathrm{Pb}$ e $\mathrm{Sr}$ na determinação da natureza das fontes das mineralizações de chumbo do Vale do Ribeira - SP e PR. In:
CONGR.BRAS.GEOL., 36. Natal, 1990. Anais... Natal, SBG. v. 3, p. 1252-1266.

TASSINARI, C.C.G.; CAMPOS NETO, M.C.; VIDAL, P. 1989. Idades e natureza da Crosta Continental primitiva da região leste do Estado de São Paulo: evidências a partir dos isótopos de $\mathrm{Nd}$, $\mathrm{Sr}$ e $\mathrm{Pb}$. In: SIMP. GEOL. SUDESTE, 1. Rio de Janeiro, 1990. Atas... Rio de Janeiro, SBG/NSP/ NRJ. p. 103-104.

TASSINARI, C.C.G.; KAWASHITA, K.; VAN SCHMUS, W.R.; TAYLOR, P.N. 1988. As idades das rochas e dos eventos metamórficos da região sudeste do Estado de São Paulo. In: CONGR.BRAS.GEOL., 35. Belém, 1988. Anais... Belém, SBG. v. 6, p. 2840-2853.

TORQUATO, J.R. 1974a. Geologia do Sudoeste de Moçamedes e suas Relações com a Evolução Tectônica de Angola. São Paulo. 243 p. (Tese de Doutoramento, IG/USP).

TORQUATO, J.R. 1974b. Considerações sobre a Idade Absoluta do Grupo Chela. Luanda, Ser. Geol.Minas de Angola, p. 1-10. (Mem. 14)

TORQUATO, JR \& AMARAL, G. 1973. Algumas idadesK-Ar do magmatismo mesozóico de Angola e sua correlação com o correspondente ao sul do Brasil. Boi. Inst. Inv. Cient. de Angola, 10:3-10.

TORQUATO, J.R.; SILVA, A.T.S.F.; CORDANI, U.G.; KAWASHITA, K. 1979. A evolução gelógica do Cinturão Móvel do Quipungo no Ocidente de Angola. An. Acad. Brás Ciên., 51:133-143.

WILLIAMSON, J.H. 1968. Least-squares fitting of a straight line. Canad. Journ.Phys., 46:1845-1847.

ZIMBRES, E.; KAWASHITA, K.; VAN SCHMUS, W.R. 1990. Evidências de um núcleo transamazônico na Região de Cabo Frio, RJ e sua correlação com o Cráton de Angola, Africa. In: CONGR.BRAS.GEOL., 36. Natal. 1990. Anais... Natal, SBG. v. 6, p. 2735-2743.

MANUSCRITO A710

Recebido em 5 de novembro de 1991 Revisão do autor em 5 de marco de 1992 Revisão aceita em 5 de março de 1992 